\title{
RELAÇÕES DE GÊNERO NOS QUADRINHOS DE SUPER-HERÓIS: A MULHER-MARAVILHA E A CIÊNCIA
}

\author{
AUTOR: VITORIA GUIMARAES DANTAS \\ CO-AUTOR/ORIENTADOR: FRANCISCO DE ASSIS NASCIMENTO JUNIOR
}

\begin{abstract}
Resumo: As relações de gênero ainda são distintas, mesmo se analisarmos conteúdos mais atuais. A mulher ainda tem papel inferior ao homem, seja no trabalho ou mídia, esse panorama é facilmente identificado nas narrativas, a partir disso esse trabalho buscou analisar quadrinhos, séries, filmes com a temática da super-heroína Mulher Maravilha, acrescentando a série mais atual como Supergirl. A Mulher-Maravilha publicada nos anos 1941 tinha objetivo de ser uma heroína feminista que defendia os direitos da mulher, uma revolução para época, entretanto a sua própria história só dá início com a chegada de Steve Trevor, volumes nos quais desvalorizam o poder da mulher normal, dando a ela apenas o poder de sedução (The menace of Dr. Poison \#2, February of 1942), a partir da edição \#178 (1968) a Mulher-Maravilha desiste de seus poderes de amazona para ficar com Steve Trevor e se torna Diana Prince, para ajudá-lo a provar que não era um traidor. Anos mais tarde, em 2017 o filme da amazona estreia, a expectativa era grande, entretanto a Gal Gadot que interpreta a heroína é exposta de forma sexualmente sugestiva. Apesar da temática e do objetivo das super-heroínas de despertar nas mulheres a luta pela igualdade, que de fato ocorreu, a objetificação do corpo ainda é algo comum, a inferioridade e a necessidade de autoafirmação mesmo passados quase 80 anos, torna imprescindível o contínuo estudo para a remoção das raízes do patriarcado e valorização da mulher perante à sociedade.
\end{abstract}

Palavras-chave: Super-heroínas, ensino de ciências, gênero. 